\title{
Effect of Nitrogen Fertilizer Sources on Grain Yield, Yield Components and Grain Quality of Rice
}

\author{
Khaled M.H. Abd-El Salam ${ }^{1}$, Ahmed M. Shaalan ${ }^{2}$ and Medhat A.E. El-Dalil ${ }^{1}$
}

\begin{abstract}
Two field experiments were conducted at the Experimental Farm of Etai El- Baroud Agricultural Research Station, Behaira Governorate, Agriculture Research Center (ARC), during 2012 and 2013 summer seasons to evaluate the response of three rice cultivars (Giza 178, Sakha 104 and Sakha 106) to nine different nitrogen sources i.e., (T1) Control, (T2) $75 \%$ of the recommended mineral nitrogen, (T3) $50 \%$ mineral +25 $\%$ blue green algae (BGA), (T4) $50 \%$ mineral $+25 \%$ organic manure (OM), (T5) $25 \%$ mineral + $25 \%$ BGA + $25 \%$ OM, (T6) $100 \%$ of the recommended mineral $\mathrm{N}$, (T7) $75 \%$ mineral $+25 \%$ BGA, (T8) $75 \%$ mineral +25 $\%$ OM and (T9) $50 \%$ mineral + $25 \%$ BGA + $25 \%$ OM. A split plot design with three replications was used. The main plots were devoted to the three rice cultivars while mineral nitrogen, blue green algae (BGA) and organic manure (OM) combinations were arranged in the sub plots. The most important results are summarized as follows: (1) Varieties were highly significantly varied in all studied characters except leaf area index (LAI), number of filled grains and protein $\%$ in both seasons. (2) Applying $50 \%$ mineral nitrogen combined with $25 \%$ blue green algae and $25 \%$ organic fertilizer showed the highest values for most studied characters in both seasons. (3) Grain yield was highly significant and positive correlated with LAI, number of panicles $/ \mathrm{m}^{2}$, number of filled grains/panicle and 1000-grain weight with $r$ - values of $0.90,0.88,0.90$ and 0.94 , respectively as averages of the two seasons.
\end{abstract}

Keywords: rice, nitrogen fertilizers, organic manure, blue green algae, yield, quality.

\section{INTRODUCTION}

Rice is one of the most important crops in Egypt and the world in addition to wheat and maize as cereal crops. In Egypt, the total cultivated area is about 1.40 million feddan (2011 season), which produces about 5.66 million tons (R.N.C., 2012). Yield per unit area increased during the last decade, from 3.83 tons/fed in 2000 to 4.02 in 2012 season. This increase may be attributed to the newly released high yielding varieties in addition to improving cultural practices especially nitrogen fertilization.

Nitrogen is considered the key element that manipulates the performance of the plants to some extent, especially cereal crops. The amount of $(\mathrm{N})$ required and management are varied depending on variety, soil conditions, cultural practices and crop rotation. Nitrogen is applied to meet the needs of the crop during the early growth stages and accumulate in the vegetative part to be utilized for grain formation (Salem et al. 2005). Also, nitrogen fertilizer has a vital role in the contents of nitrogen \% in rice grains and nitrogen uptake by rice plants (Ebaid and Ghanem, 2000).

Organic farming is a system which primarily aim to eliminate the environmental pollution and develop a more profitable and sustainable farming. Application of organic manure could increase the soil organic carbon (SOC) and that will increase soil particles aggregation, water holding capacity, infiltration rate, hydraulic conductivity and decrease bulk density. Furthermore, organic matter content serves several advantages such as conservation and slow release of nutrients, providing micronutrients and other growth factors not normally applied by inorganic fertilizers, and may also enhance microbial activity and nutrient turnover in soil.

Application of organic manure could improve the nutrient absorption, soil fertility, and reduce of fertilizer loss. Also, it is more profitable for environment protection compared with application of mineral fertilizer alone (Reganold 1995, Conacher 1998 and Liu et al. 1996). The soil with organic manure continually applied had lower bulk density and higher porosity values, porous and buffering capacity (Edmeades 2003). However, the use value of organic matter decreased along with the organic resources continually increasing under the background of agriculture with high input, high output and high efficiency (Xi et al. 2004).

Yang et al., 2004 studied the application effect of chemical fertilizer combined with farmyard manure on rice dry matter accumulation and nutrients distribution, and reported that application of organic manure combined with chemical fertilizer was propitious to the transferability and distribution of nutrients from shoot to rice grains, in addition to increase in dry matter accumulation. Also, Zhou et al. (2002, 2003) reported that the nitrogen uptake by rice and system productivity increased with the long-term combination between organic manure and chemical NPK fertilizer. Moreover, utilization of biological $\mathrm{N}_{2}$ fixation (BNF) can decrease the application of mineral $\mathrm{N}$ fertilizers, thus reducing

\footnotetext{
${ }^{1}$ Faculty of Home Economics- Minufiya University

${ }^{2}$ Faculty of Agric. Food Science \& Technology - Cairo University

Received December 02, 2014, Accepted December 30, 2014
} 
environmental risks (Raimam et al., 2007 and Radwan et al. 2008). Using bio-fertilizer or microbial inoculates to replace or increase the efficiency of chemical fertilizer, partially or totally, is effective in reducing the cost of crop production and maintaining the natural fertility of soil (Bassal et al., 1996).

This study aimed to investigate the performance of some rice varieties under different nitrogen application sources, including mineral, organic and bio sources of nitrogen and their combinations, regarding some agronomic, yield and yield components and grain quality characters.

\section{MATERIALIS AND METHODS}

Two field experiments were conducted at the Experimental Farm of Etai El- Baroud Agricultural Research Station, Behaira Governorate, Agriculture Research Center (ARC), during 2012 and 2013 summer seasons to evaluate the response of three rice cultivars (Giza 178, Sakha 104 and Sakha 106) to different nitrogen application sources as follow: $\left(T_{1}\right)$ Control, without nitrogen application, $\left(\mathrm{T}_{2}\right) \quad 75 \%$ of the recommended mineral nitrogen $(45 \mathrm{~kg} \mathrm{~N} / \mathrm{fed}$ as urea $46.5 \% \mathrm{~N}),\left(\mathrm{T}_{3}\right) 50 \%$ mineral $(30 \mathrm{~kg} \mathrm{~N} /$ fed $)+25 \%$ blue green algae (BGA), $\left(\mathrm{T}_{4}\right) 50 \%$ mineral $+25 \%$ of nitrogen added in the form of organic manure (OM), $\left(\mathrm{T}_{5}\right) 25 \%$ mineral $(15 \mathrm{~kg} \mathrm{~N} / \mathrm{fed})+25 \% \mathrm{BGA}+25 \%$ $\mathrm{OM},\left(\mathrm{T}_{6}\right) 100 \%$ of the recommended mineral nitrogen (60 Kg N/fed), $\left(\mathrm{T}_{7}\right) 75 \%$ mineral $(45 \mathrm{~kg} \mathrm{~N} /$ fed $)+25 \%$ BGA, $\left(\mathrm{T}_{8}\right) 75 \%$ mineral (45 kg N/fed) $+25 \% \mathrm{OM}$ and $\left(\mathrm{T}_{9}\right) 50 \%$ mineral $(30 \mathrm{~kg} \mathrm{~N} / \mathrm{fed})+25 \% \mathrm{BGA}+25 \%$ OM.

Blue green algae was provided by Agriculture Research Center (ARC), Giza, with the recommendation of application of 2 packages/fed to replace $25 \%$ of the added mineral nitrogen fertilization. Regarding organic manure, samples were analyzed to determine the nitrogen content and a quantity of 1330 $\mathrm{kg} /$ fed of OM were added to replace $25 \%$ of mineral $\mathrm{N}$ fertilizer. The experimental site soil had the following properties as an average of the two seasons: $\mathrm{PH}=7.8$, total organic matter $=2.3 \%$, total nitrogen $=0.20$, available $\mathrm{P}=18.3 \mathrm{ppm}$ and available $\mathrm{K}=640.0 \mathrm{ppm}$. In addition the chemical composition of cow dung was as follow: nitrogen $=11.3(\mathrm{~g} / \mathrm{Kg})$, Phosphors $=4.5$ $(\mathrm{g} / \mathrm{Kg})$, Potassium $=15.3(\mathrm{~g} / \mathrm{Kg})$, Sulfur $=1.9(\mathrm{~g} / \mathrm{Kg})$ and Zinc $=123(\mathrm{mg} / \mathrm{Kg})$.

A split plot design with three replicates was used in both season. The main plots were devoted to three rice cultivars; namely, Giza 178, Sakha 104 and Sakha 106while, the different nitrogen application sources were applied in the sub-plots. The previous crop was wheat in two seasons. Sub-plot size was $10 \mathrm{~m}^{2}$ and the sowing date in nursery was 10 May and plant were transplanted after 30 days after sowing to permanent field, in both seasons.

Random samples, each of 10 plants were taken from each sub plot to determine root growth rate (RGR) and shoot growth rate (SGR) between 15 and 30 days after transplanting on dry weight basis. Thirty days after transplanting, plant samples (five hills) were taken randomly from each plot to estimate leaf area index (LAI) and was calculated using the following equation: LAI $=$ (leaf area of fixed number of hills/ ground area occupied by these hills). At harvest, one meter square was harvested for determination of grain yield (GY) per plot then it was converted to tons/fed. Also, number of panicles $/ \mathrm{m}^{2}$, number of filled grains/panicle and 1000grain weight $(\mathrm{g})$ were determined. Furthermore, grain quality characters such as hulling, milling, broken, protein and amylose percentages were recorded according to International Rice Research Institute (IRRI 1996). Analysis of variance and correlation were carried out according to Gomez and Gomez (1984) using SAS program, version 8.0.

\section{RESULTS AND DISCUSSION}

\section{1- Effect of rice cultivars:}

Performance of the studied rice cultivars, in both seasons, are presented in tables (1,2 and 4). Data revealed that there were significant differences between rice cultivars for all studied characters except for LAI, number of filled grains/panicle and protein $\%$ in the two seasons.

Comparison between means showed that rice cultivar Sakha 106 gave the highest values for most studied characters (Tables1, 2 and 4). The average values for the two seasons were $0.35 \mathrm{~g} / \mathrm{day}, 0.71 \mathrm{~g} / \mathrm{day}$, 285.44, 25.61 $\mathrm{g}$ and $3.68 \mathrm{t} /$ fed for RGR, SGR, number of panicles $/ \mathrm{m}^{2}$, 1000-grain weight and grain yield, respectively. Furthermore, for grain quality characters, Sakha 106 rice cultivar gave acceptable values for grain quality characters reaching were 80.81, 70.97, 5.69 and 19.39 for hulling, milling, broken and amylose percentages, as averages over the two seasons, respectively .These findings are similar to those reported by El-Kholy (2004), El-Feky (2006), El-Kalla et al. (2006), El-Sherif et al. (2007), El-Nory (2008) and Radwan et al. (2008), who recorded variations between rice cultivars for agronomic and quality characters, and that could be attributed to genetic variations, between cultivars and their response to environmental conditions.

\section{2- Effect of nitrogen sources:}

The primary goal of the present study was to reduce the application of mineral nitrogen in rice growing to lower production costs and reduce the adverse effects of 
chemical fertilizers on the environment. However, the data presented in tables (1 and 2) showed that application of $75 \%$ mineral nitrogen gave significantly lower values for all studied growth characters, yield components and grain yield compared to $100 \%$ mineral nitrogen application. Abdel-Hamed (2005), AbdelSalam (2006), Gorgy (2007) and El-Refaee et al. (2008) found that increasing mineral $\mathrm{N}$ application level led to increase in vegetative growth, grain yield and yield components of rice. However, replacing $25 \%$ of the applied mineral nitrogen with its equivalent of either blue green algae or organic manure gave a slight improvement in studied characters, but still were inferior to $100 \%$ mineral $\mathrm{N}$ application. The combination of $25 \%$ mineral $\mathrm{N}+25 \% \mathrm{BGA}+25 \%$ $\mathrm{OM}\left(\mathrm{T}_{5}\right)$ gave comparable values for the studied traits, in both seasons, to application of $100 \%$ mineral $\mathrm{N}$. These findings may be attributed to the role of BGA and/or OM in improving soil fertility and stimulating healthy root development in plants. Besides, organic matter application provides food for microorganism which keeps the soil in balanced conditions. As a result, nitrogen, potassium and phosphorus will be produced naturally by feeding of microorganisms (Khatab 2010). Furthermore, the data revealed that replacement of $25 \%$ of added mineral $\mathrm{N}$ by both BGA and OM gave the highest grain yield of rice and high values for growth characters and yield components. The average values for the two seasons were 0.39, 0.84, 6.87, 311.7, 120.36, 25.35 and 4.57 for RGR, SGR, LAI, number of panicles $/ \mathrm{m}^{2}$, number of filled grains/panicle, 1000-grain weight, and GY, respectively. These values were superior, significantly or insignificantly than the application of $100 \%$ mineral nitrogen.

The data, also, indicated that application of $100 \%$ mineral nitrogen, in the second season, gave more rapid growth in early stages (as RGR and SGR) compared to application of $\mathrm{N}$ from organic or bio-sources. This may be explained by the greater availability of mineral $\mathrm{N}$ to the plant for uptake and use compared to the slow transformation of $\mathrm{N}$ from organic or bio-sources, through soil microbial activity, into a form that could be absorbed and used by the rice plant. However, $\mathrm{N}$ from organic and bio-sources was beneficial to rice plants at the end of season as indicated by the values of studied characters. Application of chemical fertilizer with organic manure was propitious to coordinate the balance of carbon and nitrogen pools, which then increased system productivity (Kaur et al. 2007). It is, also, a simple and feasible environment protection. Application of organic manure is an important approach in soil fertility improvement (Han et al. 2004). The soil organic matter would preserve nutrients balance under long term application of chemical fertilizer only, and that will increase significantly under long term application of organic manure or organic manure combined with chemical fertilizer (Wang et al. 2000; Sui et al. 2005). Organic manure application with chemical fertilizers increased the yield and nitrogen use efficiency of rice, reduced the risk of environmental pollution and improved soil fertility (Gang et al. 2008). Similar findings have been reported by Pramanik et al. (2004), Yadav (2004), Gewaily (2006) and Tabl (2008).

\section{3- The interaction between Cultivars and $\mathrm{N}$ sources:}

The interaction between cultivars and nitrogen application treatments was not significant for all studied characters except for 1000-grain weight and grain yield in both seasons. The interaction between cultivars and nitrogen sources for 1000-grain weight and grain yield/fed could be attributed to the differential response of studied cultivars to the different nitrogen application treatments. Increasing mineral nitrogen levels from 75 to $100 \%$ increased 1000 -grain weight and grain yield by 5.5 and $14.0 \%, 6.8$ and $22.1 \%$ and 5.5 and $30.2 \%$ for Giza 178, Sakha 104 and Sakha 106, respectively in 2012 season. The comparable values in 2013 season were 4.4 and $13.2 \%, 3.2$ and $20.9 \%$ and 0.4 and 27.4 $\%$ for the respective cultivars. However, application of the two nitrogen levels from different sources $(25 \%$ mineral $+25 \%$ BGA $+25 \%$ OM or $50 \%$ mineral +25 $\% \mathrm{BGA}+25 \% \mathrm{OM}$ ) revealed that 1000 -grain weight and grain yield increased by 3.9 and $41.6 \%, 7.5$ and $22.2 \%$ and 6.5 and $29.2 \%$ for Giza 178, Sakha 104 and Sakha 106, respectively in 2012 season. Respective percentages in the second season were 8.3 and $39.1 \%$, 0.8 and $20.4 \%$ and 0.8 and $21.3 \%$ for the respective cultivars.

Concerning grain quality characters, means presented in (table 4) revealed significant differences due to applied nitrogen sources and quantities, except for milling percentage in both seasons. Application of $100 \% \mathrm{~N}$ as a combination $50 \%$ mineral $\mathrm{N}+25 \%$ $\mathrm{BGA}+25 \% \mathrm{OM}$ was superior, either significantly or insignificantly, to $100 \% \mathrm{~N}$ as mineral nitrogen for all studied grain quality characters. That treatment gave higher values for hulling, protein and amylose percentages, and lower percentage of broken grain compared to $100 \%$ mineral nitrogen. The average values of both seasons were $80.83,5.54,8.79$ and 19.81 $\%$ for hulling, broken, protein and amylose percentages, respectively. However, reducing nitrogen application to $75 \%$ as combination of $25 \%$ mineral $+25 \%$ BGA + $25 \%$ OM gave statistically similar values, for those characters, to $100 \% \mathrm{~N}$ in the same combination of $\mathrm{N}$ sources. These findings emphasize the role of organic and bio-sources of $\mathrm{N}$ in increasing nutrient availability 
and balancing nutrient uptake by the rice plant which led to better quality characters. 
Table 5. Correlation between grain yield, its component and some agronomic characteristics

\begin{tabular}{|c|c|c|c|c|c|c|c|}
\hline Characters & RGR & SGR & LAI & $\begin{array}{c}\text { No. } \\
\text { panicles } / \mathrm{m}^{2}\end{array}$ & $\begin{array}{c}\text { No. Filled } \\
\text { grains/ panicle }\end{array}$ & $\begin{array}{c}\text { 1000-grain } \\
\text { weight }\end{array}$ & GY \\
\hline RGR & & $0.934^{* *}$ & 0.600 & $0.689^{*}$ & $0.699^{*}$ & $0.842^{* *}$ & $0.733^{*}$ \\
\hline SGR & & & $0.709^{*}$ & $0.749^{*}$ & $0.773^{*}$ & $0.836^{* *}$ & $0.797^{*}$ \\
\hline LAI & & & & $0.745^{*}$ & $0.786^{*}$ & $0.796^{*}$ & $0.861^{* *}$ \\
\hline No. panicles $/ \mathrm{m}^{2}$ & & & & & $0.991^{* *}$ & $0.801^{* *}$ & $0.866^{* *}$ \\
\hline No. filled grains & & & & & & $0.844^{* *}$ & $0.901^{* *}$ \\
\hline 1000-grain weight & & & & & & & $0.963^{* *}$ \\
\hline GY & & & & & & & \\
\hline
\end{tabular}

Table 6. Correlation between grain yield, its component and some agronomic characteristics

\begin{tabular}{|c|c|c|c|c|c|c|c|}
\hline & RG & & & & No. Filled & 1000-grain & \\
\hline Characters & $\mathbf{R}$ & SGR & LAI & No. panicles $/ \mathbf{m}^{2}$ & grains/ panicle & weight & GY \\
\hline RGR & & $0.855^{* *}$ & $0.847^{* *}$ & $0.882^{* *}$ & $0.755^{*}$ & $0.691^{*}$ & $0.775^{*}$ \\
\hline SGR & & & $0.873^{* *}$ & $0.824^{* *}$ & 0.656 & $0.828^{* *}$ & $0.848^{* *}$ \\
\hline LAI & & & & $0.844^{* *}$ & $0.812^{* *}$ & $0.951^{* *}$ & $0.931^{* *}$ \\
\hline No. panicles $/ \mathrm{m}^{2}$ & & & & & $0.925^{* *}$ & $0.795^{*}$ & $0.888^{* *}$ \\
\hline No. filled grains & & & & & & $0.759^{*}$ & $0.897^{* *}$ \\
\hline 1000-grain weight & & & & & & & $0.907^{* *}$ \\
\hline GY & & & & & & & \\
\hline
\end{tabular}

4- Correlation analysis of grain yield, its components and some agronomic characteristics:

Data presented in tables (5 and 6) revealed that grain yield was significantly, or highly significantly, and positively correlated to yield components, i.e., number of panicles $/ \mathrm{m}^{2}$, number of filled grains/ panicle and 1000-grain weight, in addition to growth characters, i.e. RGR, SGR and LAI, in both seasons of study. These results indicate the favorable effect of enhanced growth, in early stages (30 days after transplanting), in increasing yield components which, in turn, result in higher grain yield. The present results were in a general agreement with those reported by El-Hity and ElKeredy (1992), Ganesan (2001) and Satyavathi et al. (2001).

In conclusion, the results of the present study revealed the possibility of replacing about $25 \%$ to $50 \%$ of the mineral $\mathrm{N}$ applied to rice crop by organic and/or bio BGA sources and still maintain a comparable yield to $100 \%$ mineral $\mathrm{N}$. In addition, such applications may be a necessary approach in developing sustainable agriculture by keeping the balance of microelements and decreasing the risk of heavy metal pollution (Kong and $\mathrm{Ni}$ 2006). Application of chemical fertilizer combined with organic manure may play an important role in decreasing the soil nitrate content, increasing the soil buffering capacity and soil organic matter, improving the soil function and continually increasing yield of crops (Yang et al. 2005).

\section{REFERENCES}

Abdel-Hamed, N.N.B. (2005). Studies on the effect of some agronomic practices on characters and grain quality of rice. M. Sc. Thesis, Agron. Dept. of Agric., Kafr ElSheikh, Tanta Univ., Egypt.

Abdel-Salam, K.M.H. (2006). Effect of some agricultural practices on yield and grain quality of rice in newly reclaimed soils. M.Sc. Thesis, Fac. Agric. (Saba Basha), Alexandria Univ., Egypt.

Bassal, S.A., A.M. Abdel-All, I.O. Metwally and K.E. ElHabbak (1996). Growth and yield of rice in relation to winter preceding crops and $\mathrm{N}$ fertilizer levels. J. Agric., Sci. Mansoura Univ. 21(1): 78-88.

Conacher J., A. Conacher (1998). Organic farming and the environment, with particular reference to Australia. Biological Agriculture Horticulture. 16: 145-171.

Ebaid, R.A. and S.A Ghanem (2000). Productivity of Giza 177 rice variety growth after different winter crops and fertilized with different nitrogen levels. Egypt J. Agric. Res. 78 (2): 717-731.

Edmeades, D.C. (2003). The long-term effects of manures and fertilizers on soil productivity and quality: a review. Nutrient Cycling in Agro-ecosystems. 66: 165-180.

El- Feky, K.A. (2006). Agricultural studies on rice crop M.Sc. Thesis Fac. of Agric. Kafr El-Sheikh, Tanta Univ., Egypt.

El-Hity, M.A. and M.S. El-Keredy (1992). Genotypic variability, phenotypic correlations and path coefficient analysis of grain yield and its components in rice (Oryza sativa L.). J. Agric. Res., Tanta Univ. 18 (2): pp. 299-311. 
El-Kalla, S.E., S.M. Said, A.M. Abdel-Rahman and A.M. Kisbk (2006). Response of rice cultivar to irrigation intervals and some organic fertilizer treatment in newly reclaimed soils J. Agric. Sci. Mansoura Univ. 31 (9) 547555.

El-Kholy, W.M. (2004). Study the effect of some cultural practices on rice crop. Ph.D., Thesis, Fac. of Agric. Kafr El-Sheikh, Tanta Univ., Egypt.

El-Nory, M.I. (2008). Effect of organic and nitrogen fertilizer on the performance of some rice cultivars under North Delta conditions. M.Sc. Thesis Fac. of Agric. Kafr ElSheikh, Univ., Egypt.

El-Refaee, I.S., A.M. El-Ekhtyar and A.A. El-Gohary (2008). Improving rice productivity under irrigation interval and nitrogen fertilizer. Proc. (the second field crop Conf., Giza, Egypt, 14 -16 Oct. 333-347).

El-Sherif, E., S.A. Ghanem, R. Sorour and A. Abdou Zadan (2007). Rice production under organic and inorganic fertilization. J. Agric. Sci. Mansoura Univ., 32 (3) 16111626.

Ganesan, K.N. (2001). Direct and indirect effects of yield components on grain yield of rice hybrids. Journal of Ecobiology, 13 (1): 29-33.

Gang, XU. Ming, LI. Dong-chu, LI Ju-mei, Gin Dao-zhu, K. Yagi and Y. Hosen (2008). Effects of organic manure application with chemical fertilizers on nutrient absorption and yield of rice in Hunan of Southern China. Agricultural Science in China, 7 (10): 1245-1252.

Gewaily, E.EA. (2006). Behavior of some nutrient elements in rice soils under different irrigation intervals. Ph.D. Thesis, Fac. of Agric., Mansoura Univ., Egypt.

Gomez, K.A. and A.A. Gomez (1984). Statistical Procedures for Agricultural Research. An International Rice Research Institute Book. John Willey and Sons Inc., New York, U.S.A.

Gorgy, R.N. (2007). Effect of balanced fertilizers on productivity of hybrid and inbred rice varieties .J. Agric. Res. Kafr El-Sheikh Univ., 33 (1): 101-122.

Han B.J, Y. Chen, Y.F. Qiao, X.Z. Han and K. Meng (2004). Effect of long term application organic fertilizer on soil physiochemical properties. System Sciences and Comprehensive Studies in Agriculture, 20: 294-296.

International Rice Research Institute (IRRI) (1996). Standard Evaluation System for Rice. IRRI, Manila, Philippines. Pp. 52.

Kaur T., B.S. Brar and N.S. Dhillon (2007). Soil organic matter dynamics as affected by long-term use of organic and inorganic fertilizers under maize-wheat cropping system. Nutrient Cycling in Agro-ecosystems, 10: 110121.

Khatab, A.R. (2010). A study on rationalization of mineral fertilization through organic manure and their effects on rice crop. Ph.D. Thesis, Fac. of Agri. (Saba Basha), Alexandria University.
Kong, W.J. and W.Z. Ni (2006). Effects of integrated fertilization with commercial organic manure and chemical fertilizers on heavy metal balance in soil-rice cropping system. Chinese J. of Rice Science, 20: 517-523.

Liu X.L., Z. Gao, C.S. Liu, L.Z. Si (1996). Effect of combined application of organic manure and fertilizers on crop yield and soil fertility in a located experiment. Acta Pedologica Sinica, 33, 138-147.

Pramanik M. A., M. R. Sarkar, M.A. Islam and M.A. Samad (2004). Effect of Green Manures and Different Levels of Nitrogen on the Yield and Yield Components of Transplant Aman Rice. J. of Agron., 3 (2): 122-125.

Radwan, F.I., I. Abou- El- Seoud and A. Badr (2008). Response of two rice cultivar to blue grain green Algae, A mycorrhizae inoculation and mineral nitrogen fertilizer. J. of Plant Sci. and Biotechnology, 2 (1): 29-34.

Raimam, MP; U. Albino, M.F. Cruz, L. ovato, G.M. Spago, F. Ferracin, T.P. Lima, D.S. Goulart, T. Bernardi, C.M. Miyauchi, M. Nogueira, G. Andrade (2007). Interaction among free-living $\mathrm{N}$ - fixing bacteria isolated from Drosera villosa var. villosa and AM fungi (Glomus clarum) in rice (Oryza sativa L.). Applied Soil Ecology, 35(1):25-34.

Reganold, J. P. (1995). Soil quality and profitability of biodynamic and conventional farming systems. American Journal of Alternative Agriculture, 10: 36-45.

Rice National Campaign (R.N.C) (2012). Annual Report at R.N.C., Agricultural Research Center (A.R.C), Ministry of Agriculture \& Land Reclamation, Egypt.

Salem, A.K., B. A. Zayed, G. Ahmed and A.A. Abou-Khalifa (2005). Effect of nitrogen, potach levels and transplanting regularity on rice crop production. Egypt J. Agric. Res, 83(5B): 447-454.

SAS Institute (1999). SAS Systems. Version 8. Statistical Analysis System Institute, Cary, NC, USA.

Satyavathi, C.T., C. Bharadwaj and D. Subramanyam (2001). Variability, correlation and path analysis in rice varieties under different spacings. Indian J. of Agric. Research 35 (2): 79-84.

Sui Y.Y., X.Y Zhang, X.G Jiao, Q.C Wang and J. Zhao (2005). Effect of long-term different fertilizer applications on organic matter and nitrogen of black farmland. Journal of Soil and Water Conservation, 19: 190-194.

Tabl, D. (2008). Effect of nitrogenous and potash fertilization on productivity and grain quality of some rice cultivars. M.sc. Thesis Fac. of Agric. (Saba Basha) Alex. Univ.

Wang XD, YP. Zhang, JL. Lü, XL. Fang (2000). Effect of long-term different fertilization on properties of soil organic matter and humic acid. Scientia Agricultura Sinica, 33: 75-81.

Xi ZB., YQ. Wang and PZ. Yang (2004). The issue on organic manure in developing modern agriculture in China. Scientia Agricultura Sinica. 37: 1874-1878. 
Yadav, R.L. (2004). Enhancing efficiency of fertilizer N use in rice -wheat systems of Indo - Gangetic Plains by intercropping Sesbania aculeate in direct seeded upland rice for green manuring. Bio. Resource Technology, (93): $213-215$.

Yang, C.M., L.Z. Yang, T.M. Yan, Y.Z. Ou (2004). Effects of nutrient regimes on dry matter production and nutrient uptake and distribution by rice plant. Chinese Journal of Soil Science, 35, 199-202.
Yang S.M., F.M. Li, D. Suo, T.W. Guo, J.G. Wang, B.L. Sun and S.L. Jin (2005). Effect of long-term fertilization on soil productivity and nitrate accumulation in Gansu Oasis. Scientia Agricultura Sinica. 38: 2043-2052.

Zhou W.J., K.R. Wang, G.Y. Zhang (2003). Some effects of inorganic fertilizer and recycled crop nutrients on soil nitrogen supply and paddy rice production in the red earth region of China. Acta Ecologica Sinica, 23, 914-922.

Zhou W.J., K.R. Wang, G.Y. Zhang and X.L. Xie (2002). Effects of inorganic-organic fertilizer incorporation on productivity and soil fertility of rice cropping system in red soil area of China. Scientia Agricultura Sinica, 35, 1109-1113.

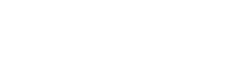

\section{تأثير المصار المختلفة النسميد النيتروجن علل المحصط ومكوناله وجودة حبوب محصط الأرز}

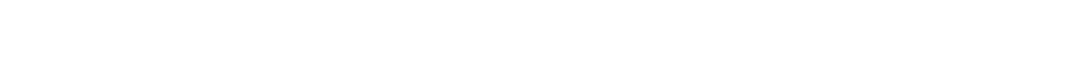

المثثقة بثلاث مكررات حيث وزعت الأصنف الثلاثة ف قى

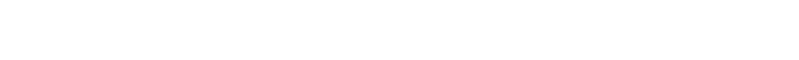
الفطع الفرعية. وفيما يلى أهم النتائج: (1) لختلفت الأصناف الفئل

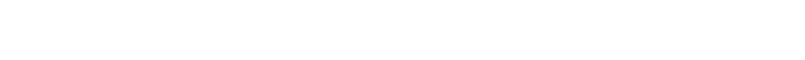

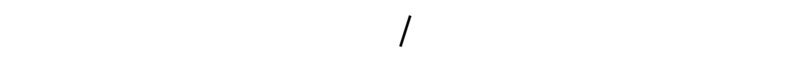

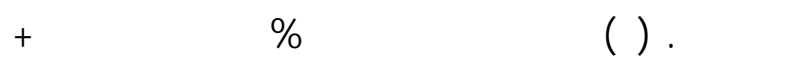

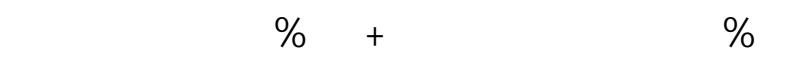

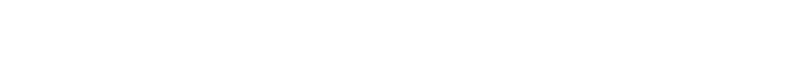

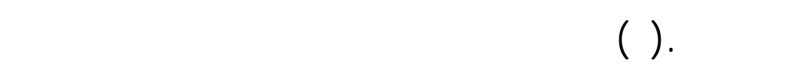

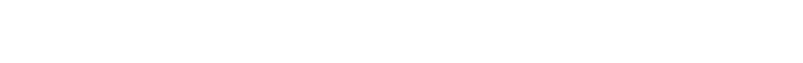

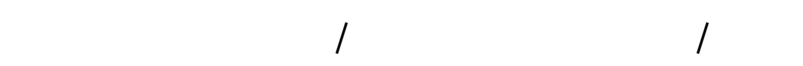

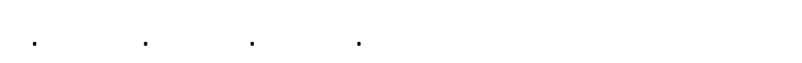
على التوالى كمتوسط للموسمين.
لجريت تجربتنان حقليتنان فى مطة البحوث الزراعية

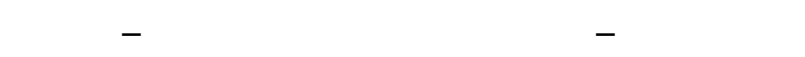

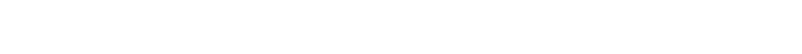

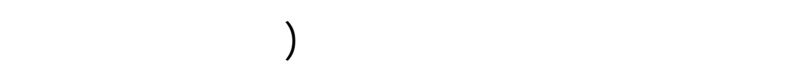

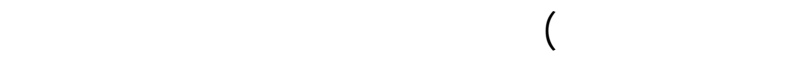

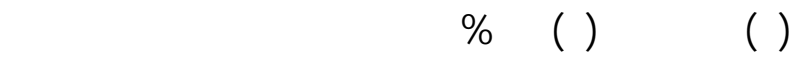

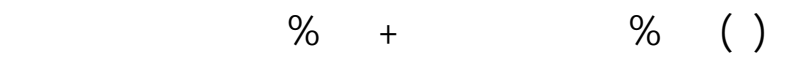

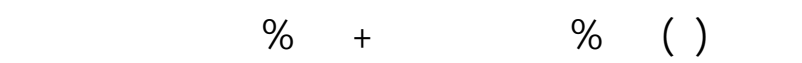

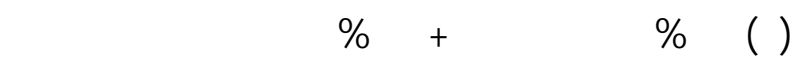

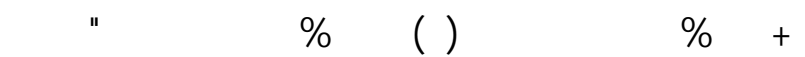

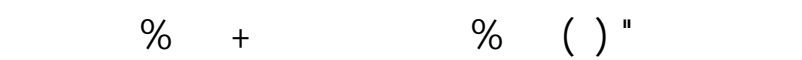

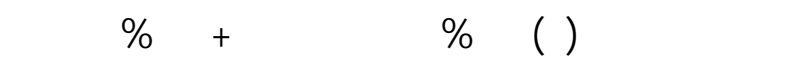

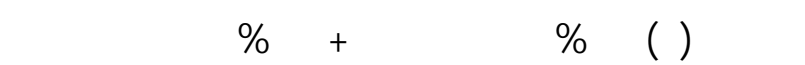

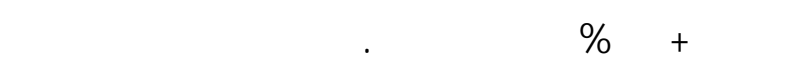

